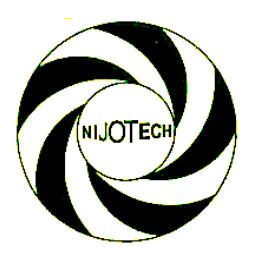

Nigerian Journal of Technology (NIJOTECH)

Vol. 39, No. 1, January 2020, pp. 293 - 300

Copyright@ Faculty of Engineering, University of Nigeria, Nsukka, Print ISSN: 0331-8443, Electronic ISSN: 2467-8821

www.nijotech.com

http://dx.doi.org/10.4314/njt.v39i1.32

\title{
WATER QUALITY ASSESSMENT OF OWIWI RIVER FOR POTENTIAL IRRIGATION OF VEGETABLES
}

\author{
A. O. Eruola ${ }^{1, *}$, A. A. Makinde ${ }^{2}$, A. O. Eruola ${ }^{3}$ and R. Oladele ${ }^{4}$ \\ $\mathbf{1 , 2 , 4}$ Department of Water Resources Management ANd Agrometeorology, University of Agriculture, \\ ABEOKUTA, OGUN STATE, NIGERIA \\ 3, Department of Chemical Sciences, YABA College of TeChNology, YABA, LAGos State, NIGERIA \\ E-mail addresses: 1eruolaao@funaab.edu.ng, ${ }^{2}$ makindeaa@funaab.edu.ng, 3/ayosky@yahoo.com, \\ ${ }^{4}$ rotimipeter6@gmail.com
}

\begin{abstract}
Understanding water quality used for irrigation and its potential negative impacts on crop growth are important for optimization of crop production. The study involved the assessment of hydrochemical properties and chemical indices of Owiwi river for irrigation of vegetables from the measured quality parameters and analyzed for important quality indices following standard test procedures. The study revealed that $\mathrm{pH}$ of water was acidic in nature resulting in low residual sodium carbonate (RSC) values showing dominance of dissolved $\mathrm{CO}_{3}$, attributed to dissolution of limestone dominant in the study area. The water was regarded as permissible water based on electrical conductivity (EC) and total dissolved solids (TDS), implying non detrimental salinity hazard in the soils. Excessive Na content (> $250 \mathrm{MMg} / \mathrm{L}$ ) in water reduces the permeability thereby influencing availability of water for the plant usage, obviously associated with low EC and sodium adsorption ratio (SAR) observed in the river water. The excess hardness resulting from high content of calcium and magnesium ions derived from limestone and chalk is undesirable mostly for esthetic reasons like plumbing of irrigation systems. Generally, the water can be classified as good for irrigation of vegetable on the bases of PI, MAR, $\% \mathrm{Na}$, SAR and $\%$ yield.
\end{abstract}

Keywords: Hydro-chemical, permeability, soil, limestone, yield.

\section{INTRODUCTION}

Water contamination resulting from natural and anthropogenic activities over the last few decades has led to continuous social and economic development problems and consequently, it's effect on human health. The extent of pollution depends largely on the degree and volume of contamination from sources [1]. Water quality monitoring is important for the protection of public health (drinking or domestic use), agriculture, industry, fishing, recreation, tourism and protection of aquatic ecosystems. The use of various types of water for irrigation and the ability to predict problems that may arise in the course of their use, invoked the need to create a water quality classification system that should be completely different from the systems used for geochemical, industrial, recreational, sanitary and other purposes. However, that irrigation water produces good yield in crop production does not imply good crop quality. This is because some of the contaminants in the irrigation water can be mobilized in soil solution by different biological and chemical mechanisms resulting in potential contamination of water adsorbed by vegetation [2]. Furthermore, irrigation water quality also influences water infiltration potentials as a result of dispersal of soil aggregates which reduces the number of large pores in the soil. With the recent support for increased consumption of vegetables in particular tomatoes for its lycopene richness and anti-oxidant activities, the need to investigate its potential use in environmental concern cannot be over emphasized.

* Corresponding author, tel: +234 8057354226 
The development of Owiwi dam water supply scheme within Abeokuta in Ogun State is borne out of the increasing population of the state. However, due to the geological formation coupled with the visible iron content of the river and the subsequent cost of treatment, the dam was initially abandoned. Nevertheless, as a result of the urgent need of irrigation facility for the Agricultural development necessary for handling the Federal Government proposed school feeding program, the Ogun State Government decided to use the facility for irrigation of vegetable in other to cultivate all year round. In other to achieve this government objective, knowledge and understanding of the hydrochemical properties of the river will contribute to its sustainable development and effective management. Hence, the characterization of the hydro-chemistry of the Owiwi River is of paramount importance, this is more so that the knowledge on comprehensive hydro-chemical characterization of the river for irrigation use is rare. Studies [3, 4] addressed aspects of flooding and water quality review. The present study, was therefore, initiated with the objective to asses Owiwi River water quality for irrigation purpose, the potential water infiltration and problem of yield potential.

\section{METHODOLOGY}

\subsection{Study area}

The study was conducted at Owiwi river, located in Abeokuta (Lat. $7^{\circ} 15^{1} \mathrm{~N}$, Long. $3^{\circ} 25^{1} \mathrm{E}$ ), Ogun state, which lies in the tropical rain forest zone of Nigeria. Owiwi river has a tropical climate, characterized by an unpredictable rainfall distribution. It has a longterm average annual rainfall and evaporation of about $1200 \mathrm{~mm}$ and $1408 \mathrm{~mm}$, respectively. The average temperature of the area ranging from $28^{\circ} \mathrm{C}$ in July/ August to $32^{\circ} \mathrm{C}$ in February/March [5]. The soil at the experimental site was categorized as a well-drained tropical ferruginous soil (A horizon of an Oxic Paleudulf of Iwo series) with $83 \%$ sand, $5 \%$ silt and $12 \%$ clay with a pH of 6 . [5]. Figure 1 shows the map of the study area.

\subsection{Water sampling and analysis}

Water samples were collected from two different water sources available in the area, namely dam and farm discharge point. A total of 12 representative water samples from each water source were collected using clean half liter polyethylene bottles. The water samples were collected during dry season November and December which marked the period irrigation is needed for vegetable cultivation in the study area. First the bottles were cleaned by diluted $\mathrm{H}_{2} \mathrm{SO}_{4}$ acid washing and then labeled with an identification number. Then, the number of the bottle was recorded on the sampling datasheet in line with the sampling location. All water samplings were completed in the morning (on the same day) and immediately taken to the Federal University of Agriculture, Abeokuta Central Laboratory for the analysis of important major cations and anions following standard methods (Table 1). Other chemical indices were derived from the measured water quality parameters. The formula adopted and sources for the calculated water quality indices are summarized in Table 2.

\subsection{Soil routine physical and chemical analysis} Soil sample was collected at $0-20 \mathrm{~cm}$ depth using soil ugar in the Federal University of Agriculture, Abeokuta experimental farm. The soil sample was airdried, sieved in $2 \mathrm{~mm}$ diameter mesh and analyzed using the following methods in Table. 3.

\section{RESULTS AND DISCUSSION}

\subsection{Properties of soils sample from the farm}

Results of the analysis of the soil samples is presented in Table. 4. The result indicated that the texture of the soils is loamy sand with organic matter content of $2.96 \mathrm{mg} \mathrm{g}^{-1}$ having a neural $\mathrm{pH}$ of 7.03 . The organic carbon, total nitrogen and the available phosphorus at the farm was $1.72 \%, 0.10 \%$ and 1.62 $\mathrm{mg} \mathrm{kg}^{-1}$ respectively. The exchangeable calcium, exchangeable magnesium, exchangeable sodium, exchangeable potassium and exchangeable hydrogen are also $3.61 \mathrm{cmol} \mathrm{kg}^{-1}, 1.54 \mathrm{cmol} \mathrm{kg}^{-1}, 0.52 \mathrm{cmol} \mathrm{kg}$ ${ }_{1}^{1}, 0.58 \mathrm{cmol} \mathrm{kg}^{-1}$ and $0.18 \mathrm{cmol} \mathrm{kg}^{-1}$,respectively. The effective cation exchange capacity (ECEC) was 6.30 $\mathrm{cmol} \mathrm{kg}{ }^{-1}$.

\subsection{Hydro-chemical composition and estimates of water quality indices of Owiwi River}

It was observed from the mean value of the measured water quality parameters and chemical indices derived from the laboratory analyzed water quality parameters of Owiwi River at the Dam and Farm area pin Table 5 that the $\mathrm{pH}$ at both sampling sources is acidic in nature $(\mathrm{pH}<7)$ and showed variability between the different water sources. 


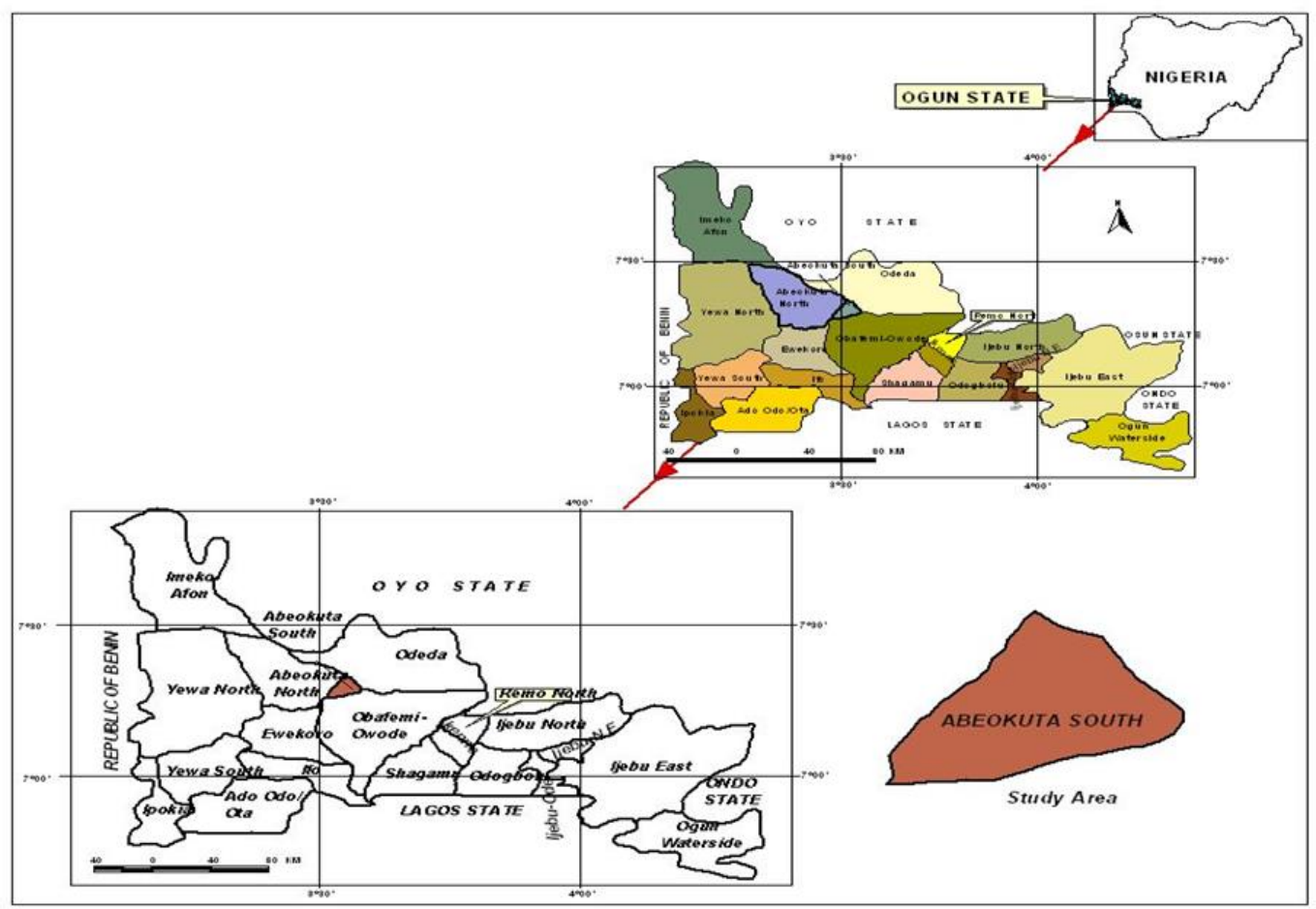

Fig. 1: Map of the study area.

Table 1: Methods adopted for water quality analysis

\begin{tabular}{lll}
\hline Quality parameter & $\mathrm{Symbol}$ & Method used \\
\hline $\mathrm{Ph}$ & $\mathrm{pH}$ & Potentiometric $(1: 2.5 \mathrm{H} 2 \mathrm{O}, \mathrm{v} / \mathrm{v})$ \\
Electrical Conductivity & $\mathrm{EC}$ & Conductometery $(1: 2.5 \mathrm{H} 2 \mathrm{O}, \mathrm{v} / \mathrm{v})$ \\
Calcium & $\mathrm{Ca}^{2+}$ & EDTA $(0.05 \mathrm{~N})$ titrimetric \\
Magnesium & $\mathrm{Mg}^{2+}$ & EDTA $(0.05 \mathrm{~N})$ titrimetric \\
Sodium & $\mathrm{Na}^{+}$ & Flame photometric \\
Potassium & $\mathrm{K}^{+}$ & Flame photometric \\
Chloride & $\mathrm{Cl}^{-}$ & Titration using 0.05 N AgNO3 \\
Carbonate & $\mathrm{CO}_{3}$ & CaTitration (with 0.01 N H2SO4) \\
Bicarbonate & $\mathrm{HCO}_{3}$ & Titration (with 0.01 N H2SO4) \\
Sulphate & $\mathrm{SO}_{4}$ & Spectro Photometric \\
\hline
\end{tabular}

Sources: $[6,7]$

Table 2: Water quality parameter estimation methods from measured parameters (All the ionic concentrations

\begin{tabular}{|c|c|c|c|}
\hline & & & \\
\hline Quality parameters & Symbol & Formula adopted & Reference/source \\
\hline Total dissolved solids & TDS & $\begin{array}{l}\mathrm{TDS}=640 \times \mathrm{EC}(\text { for } \mathrm{EC}<5 \mathrm{dS} / \mathrm{m}) \\
\mathrm{TDS}=800 \times \mathrm{EC}(\text { for } \mathrm{EC}>5 \mathrm{dS} / \mathrm{m})\end{array}$ & {$[8]$} \\
\hline Potential salinity & P.S & $\mathrm{P}: \mathrm{S}=\mathrm{Cl}+1 / 2 \mathrm{SO}_{4}^{2-}$ & [9] \\
\hline Sodium adsorption ratio & SAR & $\mathrm{SAR}=\frac{\mathrm{Na}+}{1 \mathrm{Ca} 2++\mathrm{Ma} 2+/ 2}$ & [10] \\
\hline Residual sodium carbonate & RSC & $\begin{array}{l}\mathrm{RSC}=(\mathrm{CO}-3+\mathrm{HCO}-3)-(\mathrm{Ca} 2++ \\
\mathrm{Mg} 2+)\end{array}$ & [9]Doneen (1964) \\
\hline Permeability index & PI & $\mathrm{PI}=\frac{\mathrm{Na}++\sqrt{ } \mathrm{HCO}-3}{\mathrm{Ca} 2++\mathrm{Mg} 2+} \times 100$ & [9] Doneen (1964) \\
\hline Total hardness & $\mathrm{TH}$ & $\mathrm{TH}=(\mathrm{Ca} 2++\mathrm{Mg} 2+) \times 50$ & [11]Ragunath (1987) \\
\hline Sodium percentage & $\% \mathrm{Na}$ & $\% \mathrm{Na}=\frac{\mathrm{Na}++\mathrm{K}+}{\mathrm{Na}++\mathrm{K}++\mathrm{Ca} 2++\mathrm{Mg} 2+} \times 100$ & $\begin{array}{l}\text { [12]Khodapanah et } \\
\text { al. (2009) }\end{array}$ \\
\hline Magnesium ratio & MAR & MAR $=\frac{\mathrm{Mg} 2+}{C 20} \times 100$ & [13]Paliwal (1972) \\
\hline Yield Potential & $\%$ Yield & $\%$ Yield $=100-b($ Ece $-a)$ & [14] \\
\hline
\end{tabular}

Source: [15] 
Table 3: Methods adopted for soil analysis

\begin{tabular}{|c|c|c|}
\hline Quality parameter & Symbol & Method used \\
\hline Particle size & & Pipette method [16] \\
\hline $\mathrm{pH}$ & $\mathrm{pH}$ & $\mathrm{pH}$ meter with a combination \\
\hline Organic-mater & O.M & $\begin{array}{l}\text { Walkley Black dichromate oxidation method. Percentage } \\
\text { organic matter was calculated by [17]. }\end{array}$ \\
\hline Exchangeable bases & & $\begin{array}{l}\text { flame Atomic Absorption Spectrophotometer (FAAS) adopted } \\
\text { by [18] }\end{array}$ \\
\hline Exchangeable acidity $\left(\mathrm{H}^{+}\right)$ & & $\begin{array}{l}\text { extracting with } 1 \mathrm{~N} \mathrm{KCl} \text { and determined by } \mathrm{NaOH} \text { titration } \\
\text { [19]. }\end{array}$ \\
\hline $\begin{array}{l}\text { Effective cations exchange } \\
\text { capacity }\end{array}$ & ECEC & $\begin{array}{l}\text { estimated by summing the exchangeable bases plus } \\
\text { exchangeable acidity cations. }\end{array}$ \\
\hline Total nitrogen & & Kjeldahl method $[20]$ \\
\hline Available phosphorus & & extracted by $0.03 \mathrm{M} \mathrm{NH} 4 \mathrm{~F}+0.025 \mathrm{M} \mathrm{HCl}$ [21] \\
\hline Electrical Conductivity & $\mathrm{EC}$ & Conductometery $(1: 2.5 \mathrm{H} 2 \mathrm{O}, \mathrm{v} / \mathrm{v})$ \\
\hline Calcium & $\mathrm{Ca}^{2+}$ & EDTA $(0.05 \mathrm{~N})$ titrimetric \\
\hline
\end{tabular}

The water at the farm are slightly more acidic $(\mathrm{pH}=$ 5.54) than the water in reservoirs $(\mathrm{pH}=6.51)$.

This may be due to mixing of nearby factory effluent water with Owiwi River water within the area of discharge to the farm. The acidic nature of water indicating the dominance of dissolved

$\mathrm{CO}_{3}$ rather than $\mathrm{HCO}_{3}$ ions which are known to affect $\mathrm{pH}$ of most waters. The $\mathrm{pH}$ of Owiwi River is not in the range of the recommended range for $(6-8.5)$ for irrigation purpose [22].

Salinity is very important in the determination of river water for irrigation purpose, this is because high salt content in water will renders the soil saline and also affects the salt intake capacity of the plants through the roots. Salinity in water can be evaluated using both electrical conductivity (EC) and total dissolved salts (TDS). The EC and TDS values of both water sources are different. The measured EC value was higher at the farm $(65 \mu \mathrm{S} / \mathrm{cm})$ than at the dam $(50 \mu \mathrm{S} / \mathrm{cm})$. Accordingly, TDS for both sampling points can be classified as fresh water (TDS $<1000 \mathrm{ppm}$ ) according to [23], since there values range of $24-41 \mathrm{ppm}$ thereby indicating the absence of elevated concentrations of salts. According to the EC grading standards as suggested by [24], both water sources are classified as permissible water category. Therefore, the continuation use of this low saline water for irrigation in the long term may not have any detrimental salinity hazard in the soils of the studied area.

Among the cations, the concentrations of $\mathrm{Ca}_{2}, \mathrm{Mg}_{2}, \mathrm{Na}$ and $\mathrm{K}$ ions are of paramount importance in irrigation water assessment. In this study, the soluble cations
$\mathrm{Na}$ concentration is higher at the dam $(320.2 \mathrm{MMg} / \mathrm{L})$ than at the farm discharge point $(234.6 \mathrm{MMg} / \mathrm{L})$. The $\mathrm{K}$ values are higher than the Na concentration at both sampling points. Furthermore, the $\mathrm{K}$ is higher at the dam $(426.7 \mathrm{MMg} / \mathrm{L})$ than at the farm $(398.5 \mathrm{MMg} / \mathrm{L})$. On the basis of 200 and $30 \mathrm{ppm}$ for $\mathrm{Na}$ and $\mathrm{K}$, respectively permissible limits, the water samples are unsuitable for irrigation.

The excessive sodium content in water sample reduces the permeability, and hence, the available water for the plant is reduced [25]. The high concentration of $\mathrm{K}$ in the area is as a result of the sedimentary rock nature of geology the area. Consequently, allowing $\mathrm{K}$ minerals exhibit its weak migratory ability [26] and resistant to decomposition by weathering [23]. The dominance of $\mathrm{Na}$ and $\mathrm{K}$ in the sampling point is as a result of weathering of $\mathrm{Na}$ and $\mathrm{K}$ bearing minerals/rocks(such as halite, feldspar and montmorilonite), ion (cation)-exchange process and/or agricultural activities in the area. The main source of $K$ in the area would be weathering of potash silicate minerals and agro-chemicals while the source of $\mathrm{Na}$ ion may be due to weathering of rocks (limestone), and its displacement from absorbed complex of rocks and soils by $\mathrm{Ca}$ and $\mathrm{Mg}$. Even though $\mathrm{Ca}$ and $\mathrm{Mg}$ are among the most abundant elements on Earth, their concentrations in the study area are relatively low. The concentration of Ca of $190 \mathrm{Mg} / \mathrm{L}$ for the dam and $175 \mathrm{Mg} / \mathrm{L}$ for the farm while the concentration of $\mathrm{Mg}$ of $150 \mathrm{Mg} / \mathrm{L}$ for the dam and 130 $\mathrm{Mg} / \mathrm{L}$ for the farm were above the maximum permissible limit of 80 and $35 \mathrm{ppm}$ for $\mathrm{Ca}_{2}$ and $\mathrm{Mg}_{2}$, respectively in irrigation water $[27,28]$. In the case 
study area, $\mathrm{Ca}$ is dominant as compared to $\mathrm{Mg}$ in both sampling. However, it is possible to suggest that the erosion of limestone and magnetite which are the respective rock and mineral in the area are the most common source of $\mathrm{Ca}$ and $\mathrm{Mg}$. It was obvious from table that Boron concentration of $31.3 \mathrm{Mg} / \mathrm{L}$ at the dam and $25.2 \mathrm{Mg} / \mathrm{L}$ at the farm are also higher than the maximum permissible limit of $3 \mathrm{ppm}$ at the sampling points indicating its non-suitability for irrigation based on Boron content. The concentration of boron was higher at the dam area $(31.8 \mathrm{Mg} / \mathrm{L})$ than at the farm area $(25.2 \mathrm{Mg} / \mathrm{L})$. The concentration of iron was also higher at the dam area $(0.67 \mathrm{Mg} / \mathrm{L})$ than at the farm area $(0.52 \mathrm{Mg} / \mathrm{L})$.

The Carbonate is the dominant anion in the water sources at the sampling point followed by the Sulphate ion. The concentration of $\mathrm{CO}_{3}$ and $\mathrm{SO}_{4}$ are higher at the dam (119.5 and $91.2 \mathrm{Mg} / \mathrm{L}$, respectively) than at the farm ( 96.4 and $77.2 \mathrm{Mg} / \mathrm{L}$, respectively). The $\mathrm{HCO}_{3}$ was observed to be relatively low with $55.4 \mathrm{Mg} / \mathrm{L}$ at the dam and $44.5 \mathrm{Mg} / \mathrm{L}$ at the farm. The concentration of $\mathrm{SO}_{4}$ and $\mathrm{HCO}_{3}$ at the dam and the farm were below the maximum permissible limit of 180 and 250 ppm, respectively in irrigation water. However, the concentration of $\mathrm{CO}_{3}$ at the dam and the farm were higher than the maximum permissible limit of $15 \mathrm{ppm}$ in irrigation water $[27,28]$. The primary source of these ions in water is the dissolved $\mathrm{CO}_{2}$ in rainwater that on entering in the soil dissolves more $\mathrm{CO}_{2}$. Both $\mathrm{CO}_{3}$ and $\mathrm{HCO}_{3}$ ions occur in the form of carbonate system of chemical equilibrium, usually associated with hardness of water which gives an unpleasant taste to water. The sources of $\mathrm{CO}_{3}$ and $\mathrm{HCO}_{3}$ ions are dissolution of limestone which is a carbonate rocks dominant in the study area, which results in precipitation of $\mathrm{CO}_{2}$ [26]. The sources of $\mathrm{SO} 4$ include rock weathering derived from lithology and agricultural activities around the area (phosphatic fertilizers).

Sodium adsorption ratio (SAR) is use in the assessment of sodium hazard in irrigation water, hence, it can be used in considering the suitability of water source for irrigation [29]. It is an easily measured property that gives information on the comparative concentrations of $\mathrm{Na}^{+}, \mathrm{Ca}_{2}{ }^{+}$, and $\mathrm{Mg}_{2}{ }^{+}$in soil solutions. From Table 5, the SAR values of water sampled at the Dam (4.28) and Farm (2.34) makes the water to be classified as excellent for irrigation [6].

According to [30], Irrigation water quality on the bases of hazardous effect of sodium on water can also be classified using sodium percentage (SP). It is obvious from study that the irrigation water quality can be classified as 'good to permissible' (52.5\%), as sodium percentage values of the Dam area samples is $54 \%$ and the farm is $51.8 \%$.

Accordingly, both water at sampling sources (Dam = 1059 and farm $=949)$ are classified hard $(\mathrm{TH}>1000)$. The Excess hardness associated with the sampling points is undesirable mostly for economic or esthetic reasons [11]. Hard water as observed in Owiwi River water can be associated with high content of calcium and magnesium ions, and in particular other dissolved compounds which is dominant in Owiwi River. Calcium is believed to have enters the water as calcium carbonate $\left(\mathrm{CaCO}_{3}\right)$, in the form of limestone and chalk, the predominant mineral in the study area. The predominant source of magnesium is dolomite $\left(\mathrm{CaMg}\left(\mathrm{CO}_{3}\right)_{2}\right)$. In general, water with hardness more than 200 ppm as $\mathrm{CaCO}_{3}$ will lead to scale deposits in the piping system [31]. Thus, the result suggests that most of the water samples can be problematic for plumbing of irrigation systems.

From the Table 5, it can be interpreted that the Owiwi River water at sampling points shows Residual sodium carbonate (RSC) values of -16.33 and $-15.07 \mathrm{meq} / \mathrm{l}$ at the Dam and Farm, respectively. Based on the [10], water samples have values $<1.0 \mathrm{meq} / \mathrm{l}$ and are safe for irrigation; hence, with low RSC values, indicated low $\mathrm{pH}$ and land irrigated by such water becomes fertile owing non deposition of sodium carbonate as indicated by the sandy loam nature of the soil (Table 2)

Water can be classified as Class I, Class II and Class III orders with regard to permeability index (PI). Class I and Class II waters are categorized as good for irrigation with $75 \%$ or more of maximum permeability. Class III waters are unsuitable with 25 $\%$ of maximum permeability [9]. From the Table 5, it can be demarcated that the PI values are $67.28 \%$ for the Dam area and $58.11 \%$ at the Farm area, hence, the water at sampling points fall into the Class I Category of Donnen's chart and are categorized as good for irrigation.

Generally, calcium and magnesium maintain a state of equilibrium in most waters. Though, $\mathrm{Ca}$ is dominant as compared to $\mathrm{Mg}$ in both sampling in the study area as a result of erosion of limestone and magnetite which are the respective rock and mineral in the area are the most common source of $\mathrm{Ca}$ and $\mathrm{Mg}$, it is obvious that magnesium in water will adversely affects the crop yield. For this reason, in this study magnesium hazard was evaluated by two following methods including "magnesium ratio" (\% MAR) and "calcium to 
magnesium molar ratio". From the Table 5, it is seen that the magnesium ratio for the Dam was $55.9 \%$ and $55.2 \%$ for the farm. In this study, water from both sampling points has $\mathrm{Mg}$ ratio more in the vicinity 50 $\%$, which will not affect the crop yield [13]. The moderate values of observed 'magnesium ratio' are likely due to the influence of magnetite in these areas. The result support that $\mathrm{Ca}: \mathrm{Mg}$ molar ratio in the surveyed water samples with $>1$ (Dam $=3.3$ and Farm = 3.1). $[32,33]$ have pointed out that water with a Ca:Mg molar ratio $>1$, results in an decreased SAR value, hence, indicating non detrimental effects on soil structure and crop yield as the soils is not saline.
The yield potential as estimated using the relationship between salinity in irrigation water (electrical conductivity of irrigation water) and the average rootzone salinity according to [14] revealed that electrical conductivity of irrigation water value at $50 \%$ yield for tomato with long term use of irrigation water of different quantities based on 15 to $20 \%$ leaching fraction and 50 and $65 \mu \mathrm{S} / \mathrm{cm}$ for dam and farm respectively indicating a moderately sensitive water quality for irrigation

Table 4: Some properties of soils sample from the farm.

\begin{tabular}{|c|c|c|}
\hline Quality parameter & Symbol/ Units & Farm \\
\hline $\mathrm{pH}$ & $\mathrm{pH}: \mathrm{H}_{2} \mathrm{O} 1: 2$ & 7.03 \\
\hline Organic Carbon & $0 . C(\%)$ & 1.72 \\
\hline available phosphorus & AV. P(mgkg-1) & 1.62 \\
\hline Sodium & $\mathrm{Na}^{+} \mathrm{cmol}^{-1} \mathrm{~kg}^{-1}$ & 0.52 \\
\hline Potassium & $\mathrm{K}^{+} \mathrm{cmol}^{-1} \mathrm{~kg}^{-1}$ & 0.58 \\
\hline Calcium & $\mathrm{Ca}^{++} \mathrm{cmol}^{-1} \mathrm{~kg}^{-1}$ & 3.61 \\
\hline Magnesium & $\mathrm{Mg}^{++} \mathrm{cmol}^{-1} \mathrm{~kg}^{-1}$ & 1.54 \\
\hline Hydrogen & $\mathrm{H}^{+} \mathrm{cmol}^{-1} \mathrm{~kg}^{-1}$ & 0.18 \\
\hline Total nitrogen & T. N (\%) & 0.10 \\
\hline Sand & Sand $(\%)$ & 75.2 \\
\hline Clay & Clay (\%) & 9.1 \\
\hline Silt & Silt (\%) & 13.8 \\
\hline Organic matter & O.M mg g $\mathrm{g}^{-1}$ & 2.96 \\
\hline ECEC $\mathrm{cmol}^{-1} \mathrm{~kg}^{-1}$ & ECEC $\mathrm{cmol}^{-1} \mathrm{~kg}^{-1}$ & 6.30 \\
\hline Textural class & Textural class & Sandy loam \\
\hline
\end{tabular}

Source: Field (September 2017)

Table 5: Result of hydro-chemical composition and estimates water quality indices analysis of Owiwi water sources

\begin{tabular}{|c|c|c|c|}
\hline Quality parameter & Symbol/ units & Mean Dam Source & Mean at Discharge point to the farm \\
\hline $\mathrm{Ph}$ & $\mathrm{pH}$ & 6.51 & 5.54 \\
\hline Electrical Conductivity & $\mathrm{EC}(\mu \mathrm{S} / \mathrm{cm})$ & 50.00 & 65.00 \\
\hline Total Dissolved Solid & TDS (MMg/L) & 24 & 41 \\
\hline Calcium & $\mathrm{Ca}^{2+}(\mathrm{Mg} / \mathrm{L})$ & 186.7 & 170.2 \\
\hline Magnesium & $\mathrm{Mg}^{2+}(\mathrm{Mg} / \mathrm{L})$ & 142.1 & 125.7 \\
\hline Sodium & $\mathrm{Na}^{+}(\mathrm{Mg} / \mathrm{L})$ & 320.2 & 234.6 \\
\hline Potassium & $\mathrm{K}^{+}(\mathrm{Mg} / \mathrm{L})$ & 426.7 & 398.5 \\
\hline Boron & $\mathrm{B}^{+}(\mathrm{Mg} / \mathrm{L})$ & 31.3 & 25.2 \\
\hline Iron & $\mathrm{Fe}(\mathrm{Mg} / \mathrm{L})$ & 0.67 & 0.52 \\
\hline Carbonate & $\mathrm{CO}_{3}{ }^{2-}(\mathrm{Mg} / \mathrm{L})$ & 119.5 & 96.4 \\
\hline Bicarbonate & $\mathrm{HCO}_{3}-(\mathrm{Mg} / \mathrm{L})$ & 55.4 & 44.5 \\
\hline Sulphate & $\mathrm{SO}_{4}-(\mathrm{Mg} / \mathrm{L})$ & 91.2 & 77.2 \\
\hline Sodium adsorption ratio & SAR & 4.28 & 2.34 \\
\hline Residual sodium carbonate & RSC-(meq/l) & -16.33 & -15.07 \\
\hline Permeability index & $\mathrm{PI} \%$ & 67.28 & 58.11 \\
\hline Total hardness & $\mathrm{TH}$ & 1059 & 949 \\
\hline Sodium percentage & $\% \mathrm{Na}$ & 54.0 & 51.8 \\
\hline Magnesium ratio & $\%$ MAR & 55.9 & 55.2 \\
\hline Yield Potential & $\%$ Yield & 50 & 50 \\
\hline Water infiltration problem & & Likely & Likely \\
\hline
\end{tabular}


When the irrigation water was assessed for potential water infiltration problem using the electrical conductivity of irrigation water and SAR, it was obvious that the low electrical conductivity of irrigation water and SAR in both the dam and the farm will result in water infiltration problem.

\section{CONCLUSION}

The hydrochemical composition of Owiwi river water has been analyzed and characterized based on their chemical compositions. Hydro-chemical analysis data has revealed that the $\mathrm{pH}$ of Owiwi River water is acidic in nature resulting in low RSC values an indication dominance dissolved $\mathrm{CO}_{3}$ with average value greater than $100 \mathrm{Mg} / \mathrm{L}$. This is an attribute of dissolution of limestone a carbonate rocks dominant in the study area. The use of this water for irrigation makes the land fertile owing non deposition of sodium carbonate as indicated by the sandy loam nature of the soil. The water can be regarded as permissible water on the bases of EC and TDS, implying that the continuous usage of water for irrigation in the long term may not have any detrimental salinity hazard in the soils. The excessive sodium content (> $250 \mathrm{Mg} / \mathrm{L}$ ) in water sample reduces the permeability thereby influencing available of water for the plant usage, a phenomenon that was obvious in the low electrical conductivity and SAR observed in the river water. The excess hardness associated river water is undesirable mostly for aesthetic reasons in particular plumbing of irrigation systems. The Hard water as observed in Owiwi River water can be associated with high content of calcium and magnesium ions, believed to have entered the water as calcium carbonate ( $\mathrm{CaCO} 3)$, in the form of limestone and chalk, the predominant mineral in the study area. Generally, the water can be classified as good for irrigation on the bases of PI. \% MAR, \% Na and SAR. The potential percentage yield of vegetable production is assured from moderately sensitive water quality for its irrigation as obviously noticed from the study.

\section{REFERENCES}

[1]. Thornton, I. Metal Contamination of Soils in Urban Areas. In: Bullock, P. and

Gregory, P.J., Eds., Soils in the Urban Environment, Blackwell, Oxford, 1991, pp 4775
Yussuf, A.A., Arowolo, T.A and Bamgbose, O. "Cadmium, copper and Nickel levels in Vegetables from industrial and residential area of Lagos city, Nigeria", Journal of Food Chemistry and Toxicology. Vol. 41, 2003, pp 375-378, Nigerian Journal of Technology, Vol. 1, Number 1, 1975, pp 3-6 (for journal Articles).

[2]. Oyegoke, S.O. and Sojobi, A.O. " Developing appropriate techniques to alleviate the Ogun River Network annual flooding problems", International Journal of Scientific and

[3]. Engineering Research, Vol. 3, Number 2, 2012, pp 1-7.

[4]. Akinyemi, J.O. and Souley, S.O. "Monitoring the Quality of Some Sources of Irrigation Water in Different Parts of Ogun State, Nigeria", International Conference on Environment Systems Science and Engineering. Science Direct. Vol. 9, 2014, pp 123- 128. Available online at www.sciencedirect.com

[5]. Olasantan, F.O. " Cassava cultivation management for sustainable vegetable production in intercropping with okra", Journal of Sustainable Agriculture. Vol. 2, Number 2, 2005, pp 53 - 68.

[6]. UNESCO/WHO/UNEP. Water Quality Assessment - A Guide to Use of Biota, Sediments, and Water in EnvironmentalMonitoring, 2nd ed. 1996.

[7]. APHA (American Public health Association), Standard Methods for the Examination of Water and Waste water, 19thEdition, 1995. The American Water Works Association (AWWA) and the Water Environment Federation (WEF).

[8]. Dinka, M.O., Loisjkandl, W., Ndambuki, J.M. "Hydrochemical modelling for Lake Basaka: development and application of a conceptual water budget model", Environmental Monitoring Assessment. Vol. 186, 2014, pp 5363-5379.

[9]. Doneen, L.D. Notes on Water Quality in Agriculture. Water Science and Engineering Paper 4001. Department of Water Sciences and Engineering, Univ. of California, 1964.

[10]. USSL (United States Salinity Laboratory), "Diagnosis and Improvement of Saline and Alkali Soils". Agricultural Handbook, Vol. 60, 1954, USDA, pp 160pp.

[11]. Ragunath, H.M. Groundwater. Wiley Eastern Ltd, New Delhi. 1987 pp 563-569. 
[12]. Khodapanah, L., Sulaiman, W.N.A., Khodapanah, N. "Groundwater quality assessment for different purposes in Eshteharddistrict, Tehran, Iran", European Journal of.Science Research Vol. 36, Number 4, 2009, pp 543-553.

[13]. Paliwal, K.V. Irrigation with Saline Water. ICARI Monograph (New Series). New

[14]. Delhi, 1972, Number 2, pp 198.

[15]. Maas, E.V. and Grattan, S.R. "Crop yields as affected by salinity". In R.W.Skaggs and J. van Schilfgaarde, eds., Agronomy Monograph Vol. 38, 1999, ASA, CSSA, SSSA, Madison, WI.

[16]. Megersa, M., Beyene, A., Ambelu, A. and Woldeab, B. , "The use of indigenous plant species for drinking water treatment in developing countries", Journal of Biodiversity and Environmental Sciences. Vol. 5, Number 3, 2015, pp 269-281.

[17]. Gee, G.W. and J.W. Bauder. Particle Size Analysis. In: Methods of Soil Analysis, Part A. Klute (ed.). America Society of. Agronomy., Madison, WI, Vol. 9, Number 2, 1986, pp 383411.

[18]. Nelson, D.W. and L.E. Sommers. Total carbon, organic carbon and organic matter: In: A.L. Page, R.H. Miller and D.R. Keeney) Methods of soil analysis. Part 2 Chemical and Microbiological Properties, 1982, pp 539-579.

[19]. Okalebo, J.R., Gathua, K.W., Woomer, P.L. Laboratory Methods of Soil and Plant Analysis: a Working Manual. TSBF,Nairobi. 1993.

[20]. Sims, J.T., Line requirement. In D.L Sparks (ed) Method of soil analysis part- 3. SSSA and ASA Madison, WI. 1996, pp 491-515.

[21]. Jackson, M.L. Soil Chemical Analysis. Constable and Co. Ltd., London, 1962.

[22]. Bray, R.H. and Kurtz, L.T. "Determination of Total Organic and Available Forms of Phosphorus in Soils". Soil Science, Vol.59, 1945, pp 39-45. Ayers, R.S. and Westcot, D.W., "Water quality for agriculture". Food and Agriculture

[23]. Organization (FAO) of the United Nations. FAO Irrigation and Drainage Paper Number 29(Rev.1), 1985, pp 1-144.
[24]. Pradhan, B. and Pirasteh, S. "Hydro-chemical analysis of the ground water of the basaltic catchments: upper Bhatsai region,Maharastra". Open Hydrology Journal. Number 5, 2011, pp 51-57.

[25]. Wilcox, L. V. Classification and use of Irrigation water. US Dept of Agriculture, Washington, Circular Number 9, 1955, pp 69.

[26]. Arveti N, Sarma MRS, Aitkenhead-Peterson JA, Sunil K. "Fluoride incidence in groundwater: a case study from Talupula, Andhra Pradesh, India". Environmental Monitoring Assessment Vol. 172, 2011, pp 427-443

[27]. Nikanorov, A.M., Brazhnikova, L.V. Types and Properties of Water II: Water Chemical Composition of Rivers, Lakes andWetlands, 2012.

[28]. Duncan RR, Carrow RN, Huck M. "Understanding water quality and guidelines to management (an overview of challenges for water usage on golf courses for the 21 century)". USGA Green Section Record, 2000, pp 14-24.

[29]. Sharifi Z, Safari Sinegani A A. "Arsenic and other irrigation water quality indicators of groundwater in an agricultural area of Qorveh Plain, Kurdistan, Iran". America

[30]. Eurasian Journal of Agricultural Environmental Science, Vol. 12, Number 4, 2012, pp 548-555.

[31]. Todd DK, Mays L.W. Groundwater hydrology. 3rd edn. Wiley, Hoboken, NJ, 2005, pp 656

[32]. Wilcox, LV. Determining the quality of irrigation water. Dept. of Agriculture, USA, 1958, pp 6

[33]. Van der Aa, M. "Classification of Mineral Water Types and Comparison with Drinking Water Standards". Environmental geology. Vol.44, Number 5, 2003, pp 554-563

[34]. Jalali, M. "Effect of sodium and magnesium on kinetics of potassium release in some calcareous soils of western Iran". Geoderma Vol. 145, 2008, pp 207-215

[35]. Joshi DM, Kumar A, Agrawal N. "Assessment of the irrigation water quality of River Ganga in Haridwar District India", Journal of Chemistry. Vol. 2, Number 2, 2009, pp 285-292 